Bangladesh J. Plant Taxon. 25(2): 227-239, 2018 (December)

(C) 2018 Bangladesh Association of Plant Taxonomists

\title{
THREE NEW SPECIES OF ARACEAE FROM BANGLADESH
}

\author{
Hosne Ara ${ }^{1}$ AND Md. AbUl Hassan ${ }^{2}$ \\ Bangladesh National Herbarium, Chiriakhana Road, Mirpur-1 \\ Dhaka-1216, Bangladesh
}

Keywords: Alocasia hararganjensis; Alocasia salarkhanii; Typhonium elatum; New species; Araceae; Bangladesh.

\begin{abstract}
Three new species belonging to two genera of Araceae from Bangladesh, namely Alocasia hararganjensis H. Ara \& M.A. Hassan, Alocasia salarkhanii H. Ara \& M.A. Hassan and Typhonium elatum H. Ara \& M.A. Hassan are described and illustrated. Diagnostic morphological characters of each of the new species are provided. A comparative morphological characteristic for each new species with their closest described species has also been provided.
\end{abstract}

\section{Introduction}

The family Araceae de Juss. is represented globally by 3,645 species under 144 genera (Boyce and Croat, 2011). The family is represented in Bangladesh by 27 genera and 109 species, of which 80 species are wild and 29 are cultivated (Ara, 2016).

During revisionary work of the family Araceae from Bangladesh the first author made an extensive field survey (137 field trips) throughout the country, especially in the hilly forest areas during 1988-2014 and collected 2,698 aroid specimens. Most of the collected specimens were identified by the first author. However, fifteen specimens remain distinct from any previously described and named species by different morphological characters. Twelve specimens identified belonging to the genus Alocasia (Schott) G. Don were not identical to any other described species. However, nine specimens of Alocasia (Schott) G. Don are closely related to Alocasia fallax Schott and remaining three are closely related to A. fornicata (Roxb.) Schott. Rest three specimens were identified as to belonged to the genus Typhonium Schott. These specimens are morphologically related to Typhonium trilobatum (L.) Schott. These specimens were critically examined and compared with the identified specimens of Alocasia (Schott) G. Don and Typhonium Schott available at BK, BKF, BM, CAL, DACB, K, DUSH (Dhaka University Salar Khan Herbarium), HCU (Herbarium of Chittagong University), BCSIRH (Herbarium, Bangladesh Council for Scientific and Industrial Research) and BFRIH (Herbarium, Bangladesh Forest Research Institute). Moreover, consultation of the relevent literatures (Wallich, 1829-1849; Roxburgh, 1832; Wight, 1843-1845; Hooker, 1893; Jackson, 1893-1955, Prain, 1903; Engler, 1920; Engler and Krause, 1920; Hu, 1968; Nicolson, 1976, 1979, 1987; Nasir, 1978; Nicolson and Sivadasan, 1981; Mayo, 1985; Karthikeyan et al., 1989; Hay, 1991, 1993, 1998, 1999; Noltie, 1994; Sriboonma et al. 1994; Sookchaloem, 1995; Mayo et al., 1997; Hetterscheid and Boyce, 2000; Toha, 2000; Boyce, 2007; Li et al., 2010) on the family Araceae revealed that collected specimens differed from other described species of the genus Alocasia (Schott) G. Don and Typhonium

${ }^{1}$ Corresponding author, Email: bnh_mirpur@yahoo.com

${ }^{2}$ Department of Botany, University of Dhaka, Dhaka-1000, Bangladesh. 
Schott. After critical study these specimens were recognized as new species, Alocasia hararganjensis sp. nov., Alocasia salarkhanii sp. nov. and Typhonium elatum sp. nov. The new species are described and illustrated below.

\section{Results and Discussion}

1. Alocasia hararganjensis $H$. Ara \& M.A. Hassan, sp. nov.

(Figs 1 \& 2).

Diagnosis: Alocasia hararganjensis H. Ara \& M.A. Hassan is closely related to A. fallax Schott but readily differentiated by the leaf shape which are narrowly to ovate sagittate with acute tip; tip of the cataphylls c. $8 \mathrm{~cm}$ long; and no sterile male zone above the sterile interstice.

Holotype: Bangladesh, Moulvibazar district, Gazipur beat, Hararganj reserve forest, 21.05.2005, Hosne Ara HA 1740 (DACB).

Massive sub-arborescent pachycaul herb, c $3.5 \mathrm{~m}$ high. Stem erect to decumbent, c. $10 \mathrm{~cm}$ in diameter, c $2.3 \mathrm{~m}$ long, clothed in the brown remains of old leaf bases. Leaves several together in terminal crown, held almost erect or slightly curved; petiole c. $1.2 \mathrm{~m}$ long, sheathing c. $1 / 2$ from the base of petiole, eglandular, light green, wing of sheath out-rolled; blade narrowly sagittate to ovate-sagittate, slightly glossy, leathery, glabrous, dark-green adaxially, pale green abaxially, usually bullate, $40-50 \mathrm{~cm}$ long, base $40-48 \mathrm{~cm}$ in diameter, margin entire to slightly sinuate; anterior lobes 35-42 cm long with apiculate tip c. $1 \mathrm{~cm}$ long; anterior costa prominent on both surfaces, glabrous, primary veins 7-11 on each side, prominent on both surfaces, diverging at $45^{\circ}$ $70^{0}$; secondary veins flush on both surfaces; interprimary collective veins well-defined; submarginal vein c. $3 \mathrm{~mm}$ from the margin; glands in the axils of primary veins absent or extremely inconspicuous; posterior lobes 30-35 cm long, rounded, peltate, c. $1.9 \mathrm{~cm}$ long; posterior costae straight. Inflorescences 10 in the centre of the leafy crown, bloom one after another, subtended by cataphylls; cataphylls $66-68 \mathrm{~cm}$ long, tip of the cataphylls pointed, c. $8 \mathrm{~cm}$ long, green; peduncle smooth, 50-64 cm long, $1.0-1.5 \mathrm{~cm}$ in diameter at the base, green. Spathe $18.5-21.0 \mathrm{~cm}$ long, constricted at level of sterile zone of spadix; lower spathe $4.5-5.0 \mathrm{~cm}$ long, light green, broadly ovoid-cylindric; limb 14-16 cm long, 6.5-7.0 cm in diameter, light greenish yellow, thinly leathery. Spadix shorter than spathe, $12-15 \mathrm{~cm}$ long, sessile. Female zone 1.8-2.0 cm long, 1.5-2.0 $\mathrm{cm}$ in diameter at the base, with 120-200 close-packed pistils; ovary green, ovoid to subglobose, 2-3 x 2.0-2.3 mm, unilocular, with basal placenta; style 0.5-0.8 $\mathrm{mm}$ long, $0.6 \mathrm{~mm}$ in diameter, cream coloured; stigma subglobose, shallowly 3-4 lobed, the lobes rounded, creamy; sterile interstice 2.0-2.5 cm long, with 7-8 whorls of rhombohexagonal synandrodia, the lowermost whorls isodiametric with female zone and resembling connate staminodes; sterile male zone absent above the sterile interstice; male zone creamy, $2.5-3.5 \mathrm{~cm}$ long, $1.0-1.5 \mathrm{~cm}$ in diameter; synandria creamy, rhombo-hexagonal, $2.0-2.3 \mathrm{~mm}$ in diameter, opening through apical slits; appendix ivory, 5.5-7.5 cm long, slightly thicker than the male zone at the base, then tapering gradually to a fine point, smooth to faintly rugose. Fruits yellowish (usually does not mature), rather small, 3-4 $\mathrm{mm}$ in diameter; fruiting peduncles 40-59 $\mathrm{cm}$ long, bend, fruiting spathe whitish, pendulous, 5-6 cm long, the spathe dehiscing longitudinally.

Flowering period: March to October.

Ecology: Grows on the hill slopes as undergrowth.

Distribution: North-Eastern part of Bangladesh, Habiganj and Moulvibazar districts.

Specimens examined: Habiganj: Kalenga beat, Kalenga, 03.07.2005, Hosne Ara HA 1771 (DACB); Moulvibazar: Gazipur beat, Hararganj reserve forest, 07.05.2003, Hosne Ara HA 315 (DACB); Sreemongal, Lawachara reserve forest, 15.05.2005, Hosne Ara HA 1468 (DACB); Madhabkundo, 20.05.2005, Hosne Ara HA 1707 (DACB); Gazipur beat, Hararganj reserve forest, 21.05.2005, Hosne Ara HA 1740 (DACB); Lawachara reserve forest, 04.07.2005, Hosne Ara HA 
1779 (DACB); Gazipur beat, Hararganj forest, 05.07.2005, Hosne Ara HA 1804 (DACB); Dhaka: Bangladesh National Herbarium garden (Cultivated), 22.06.2015, Hosne Ara HA 2885 (DACB) [Originally collected from Hararganj reserve forest under Moulvibazar district].

Etymology: The species is named after the type locality-Hararganj in Moulvibazar district, from where the species was first collected.

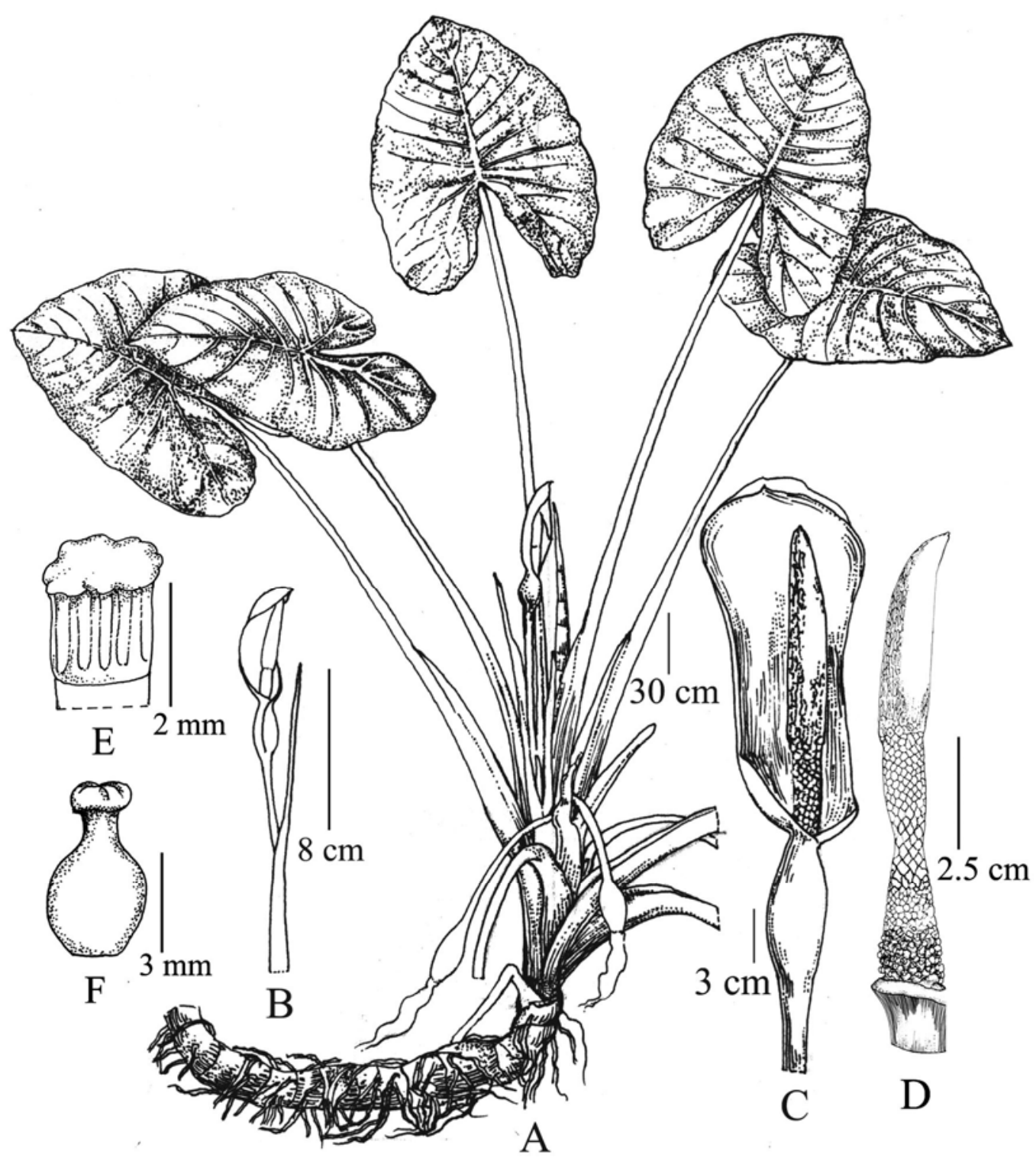

Fig. 1. Alocasia hararganjensis H. Ara \& M.A. Hassan, sp. nov.: A. Habit; B. Cataphyll; C. Inflorescence; D. Spadix; E. Synandrium; F. Gynoecium. 

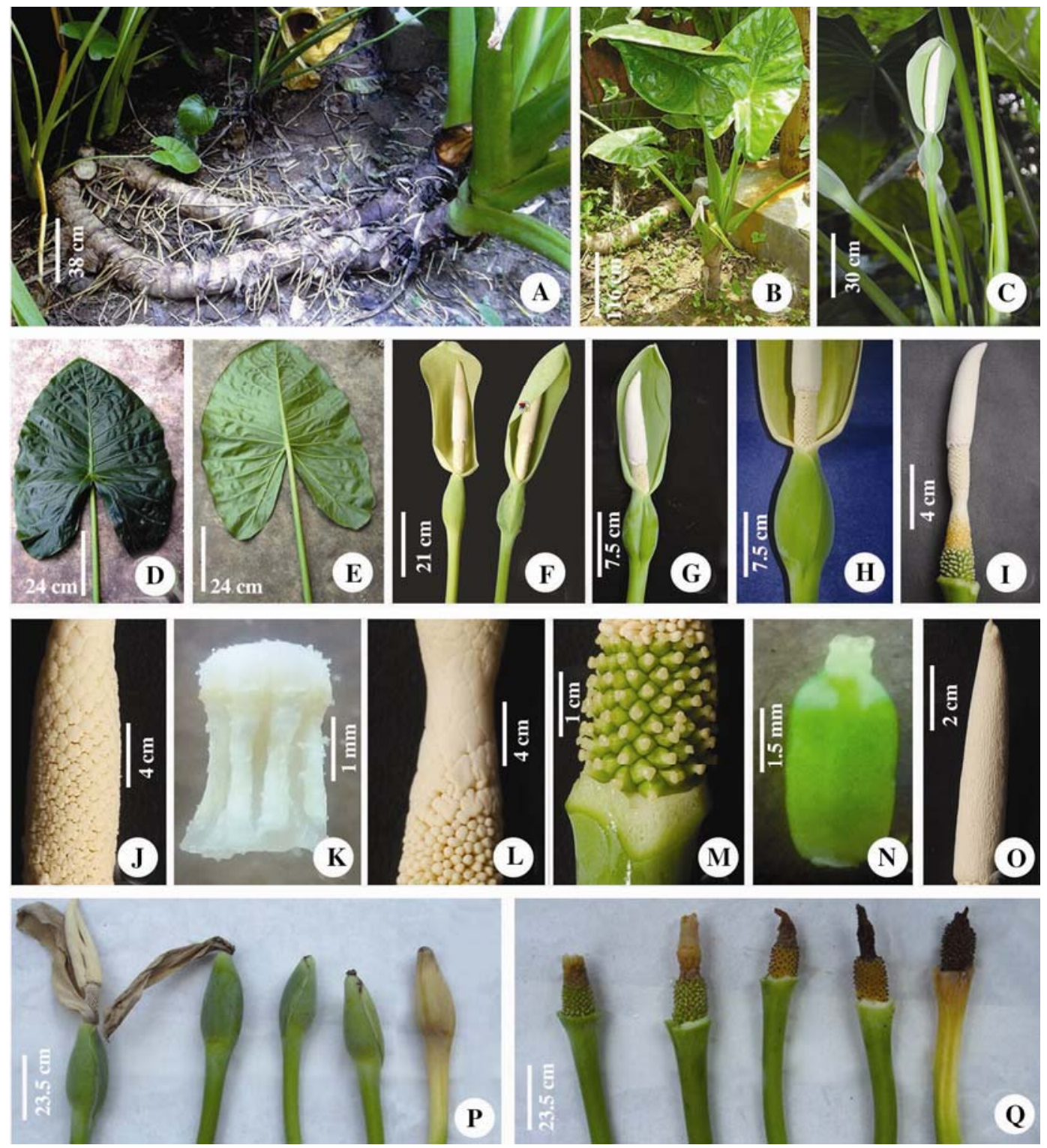

Fig. 2. Alocasia hararganjensis H. Ara \& M.A. Hassan, sp. nov.: A. Tuber; B. Habit-at BNH garden; C. Flower with cataphyll; D. Upper portion of the blade; E. Lower portion of the blade; F-H. Inflorescence; I. Spadix; J. Male zone; K. Synandrium; L. Sterile interstice; M. Lower portion of the spadix; N. Gynoecium, O. Appendix; P-Q. infructescence.

Note: The chromosome number has been determined for the new species Alocasia hararganjensis, and $2 \mathrm{n}$ chromosome number for this species appears to be 30 .

The major morphological differences between the new species Alocasia hararganjensis $\mathrm{H}$. Ara \& M.A. Hassan and its closely allied species Alocasia fallax Schott are outlined in Table 1. 
Table 1. Morphological comparison of Alocasia hararganjensis H. Ara \& M.A. Hassan, sp. nov. with Alocasia fallax Schott.

\begin{tabular}{|c|c|c|}
\hline Characters & $\begin{array}{l}\text { Alocasia hararganjensis H. Ara \& } \\
\text { M.A. Hassan, sp. nov. }\end{array}$ & Alocasia fallax Schott \\
\hline Leaf shape & $\begin{array}{l}\text { Narrowly ovate to ovate sagittate, tip } \\
\text { acute }\end{array}$ & Round and crisped, tip round \\
\hline Cataphyll & $\begin{array}{l}\text { Tip of the cataphylls long pointed, } \mathrm{c} \text {. } \\
8 \mathrm{~cm} \text { long }\end{array}$ & $\begin{array}{l}\text { Tip of the cataphylls shortly } \\
\text { pointed, c. } 2.8 \mathrm{~cm} \text { long }\end{array}$ \\
\hline Spadix & $\begin{array}{l}\text { Male zone } 2.5-3.5 \mathrm{~cm} \text { long } \\
\text { (not less than } 2.5 \mathrm{~cm} \text { long) }\end{array}$ & $\begin{array}{l}\text { Male zone c. } 1.8 \mathrm{~cm} \text { long } \\
\text { (not more than } 2 \mathrm{~cm} \text { long) }\end{array}$ \\
\hline Sterile male zone & Absent above the sterile interstice & Present above the sterile interstice \\
\hline Chromosome number (2n) & 30 & 28 (Sultana et al., 2011) \\
\hline
\end{tabular}

Conservation status: Near threatened (IUCN, 2017). Restricted distribution. Both in situ and ex situ conservation measures are suggested.

2. Alocasia salarkhanii H. Ara \& M.A. Hassan, sp. nov.

(Figs 3 \& 4).

Diagnosis: Alocasia salarkhanii H. Ara \& M.A. Hassan is closely related to Alocasia fornicata (Roxb.) Schott but can be easily differentiated by the colour of petiole and peduncle deep purple; shape of lamina long elliptic; number of inflorescences groups less than 4; length of style c. 0.5 $\mathrm{mm}$ long; male zone c. $2.3 \mathrm{~cm}$ long; and width of the appendix base and male zone are equal.

Holotype: Bangladesh, Moulvibazar district, Lawachara reserve forest, 15.05.20005, Hosne Ara HA 1467 (DACB).

Small to moderately robust herb. Stem erect to decumbent, up to $4 \mathrm{~cm}$ in diameter, c. $60 \mathrm{~cm}$ long, clothed in the brown remains of old leaf bases. Leaves several together, held almost erect or slightly curved; petiole $35-52 \mathrm{~cm}$ long, sheathing c. 1/3 from the base of petiole, eglandular, deep purple, wings of the sheath out-rolled; blade hastato-sagittate, rather narrowly triangular, margin entire to slightly undulate, glossy, leathery, dark green, glabrous adaxially, pale green and pubescent abaxially, $31-51 \mathrm{~cm}$ long, $14.0-21.5 \mathrm{~cm}$ in diameter at the base; anterior lobes $18-33 \mathrm{~cm}$ long with apiculate tip 0.6-1.0 cm long; anterior costa prominent on both surfaces, glabrous on both surfaces, primary veins 6 on each side, prominent on both surfaces, diverging at $45^{\circ}-90^{\circ}$, secondary venation flush on both surfaces, mostly arising from the primary veins at a wide angle, then deflected towards the margin, forming variously well-defined interprimary collective veins or these absent, interprimary collective veins when present weakly undulating to strongly zig-zag at base broad acute angles; submarginal vein $0.8-1.0 \mathrm{~cm}$ from the margin; glands in the axils of primary veins absent or extremely inconspicuous; posterior lobes $13-18 \mathrm{~cm}$ long, acute, peltate, 2.3-3.0 cm long; posterior costae straight to incurved. Inflorescences 3 in the center of the leaf crown, bloom one after another, subtended by a cataphyll, cataphyll up to $25 \mathrm{~cm}$ long, purple; peduncle deep purple, smooth, $26-31 \mathrm{~cm}$ long, $0.7-1.3 \mathrm{~cm}$ in diameter at the base. Spathe c. $15 \mathrm{~cm}$ long; lower spathe convolute, c. $4.2 \mathrm{~cm}$ long, green; limb c. $11.7 \mathrm{~cm}$ long, c. $4.8 \mathrm{~cm}$ in diameter, light yellowish with violet or pink mixed on both sides. Spadix shorter than spathe, c. $11.5 \mathrm{~cm}$ long. Lower fertile female zone c. $1 \mathrm{~cm}$ long; sterile female zone c. $0.5 \mathrm{~cm}$ long, c. $1.3 \mathrm{~cm}$ in diameter at the base; pistil closely packed; ovary sub-globose, green, c. 2 × $2 \mathrm{~mm}$, unilocular, with basal placenta; style distirct, stout, c. $0.5 \mathrm{~mm}$ long, c $0.8 \mathrm{~mm}$ in diameter, light yellow; stigma 3-4 lobed, lobes acute, light yellow; sterile interstice c. $2 \mathrm{~cm}$ long, narrower than the fertile zones, 


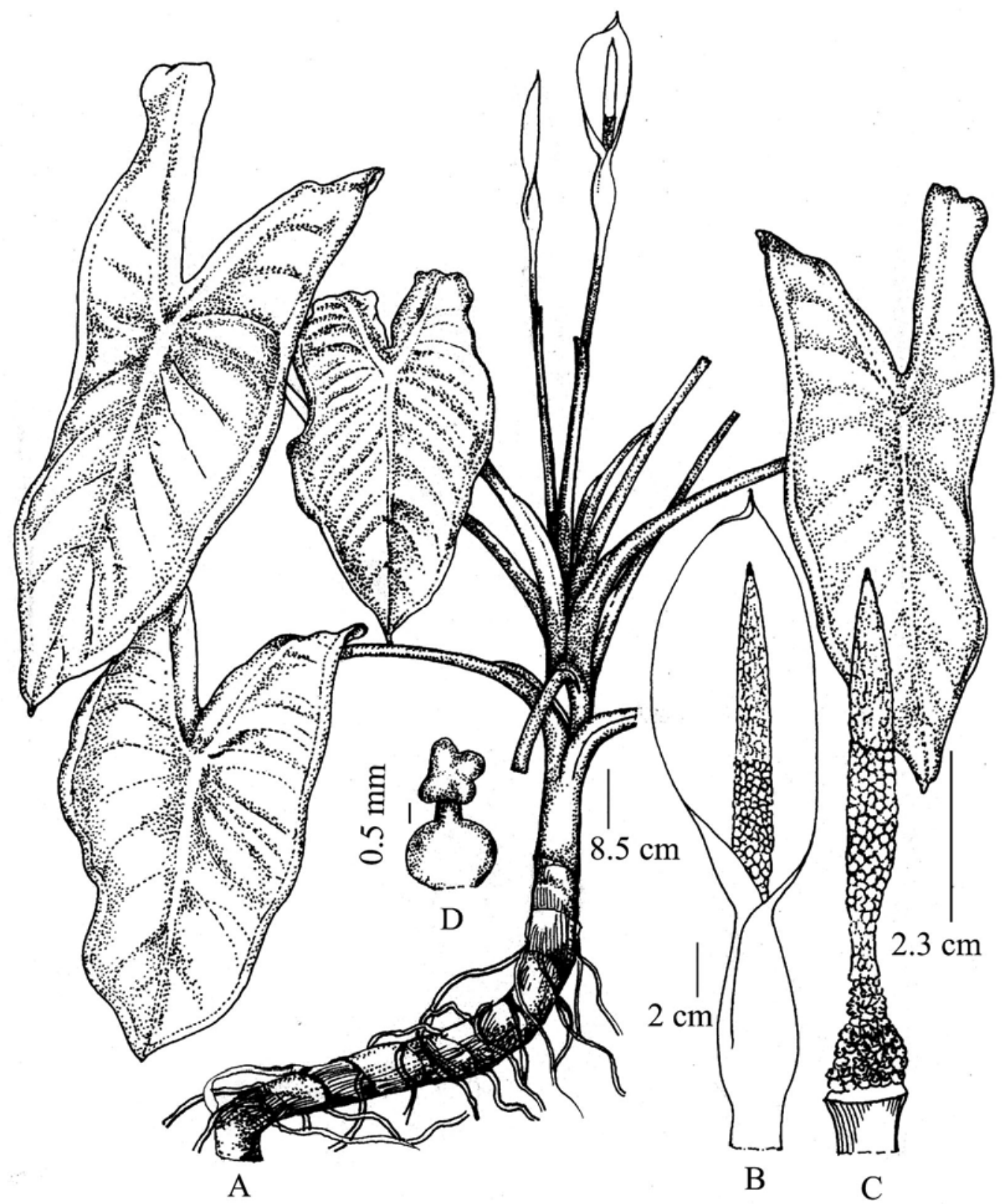

Fig. 3. Alocasia salarkhanii H. Ara \& M.A. Hassan, sp. nov.: A. Habit; B. Inflorescence; C. Spadix; D. Gynoecium. 

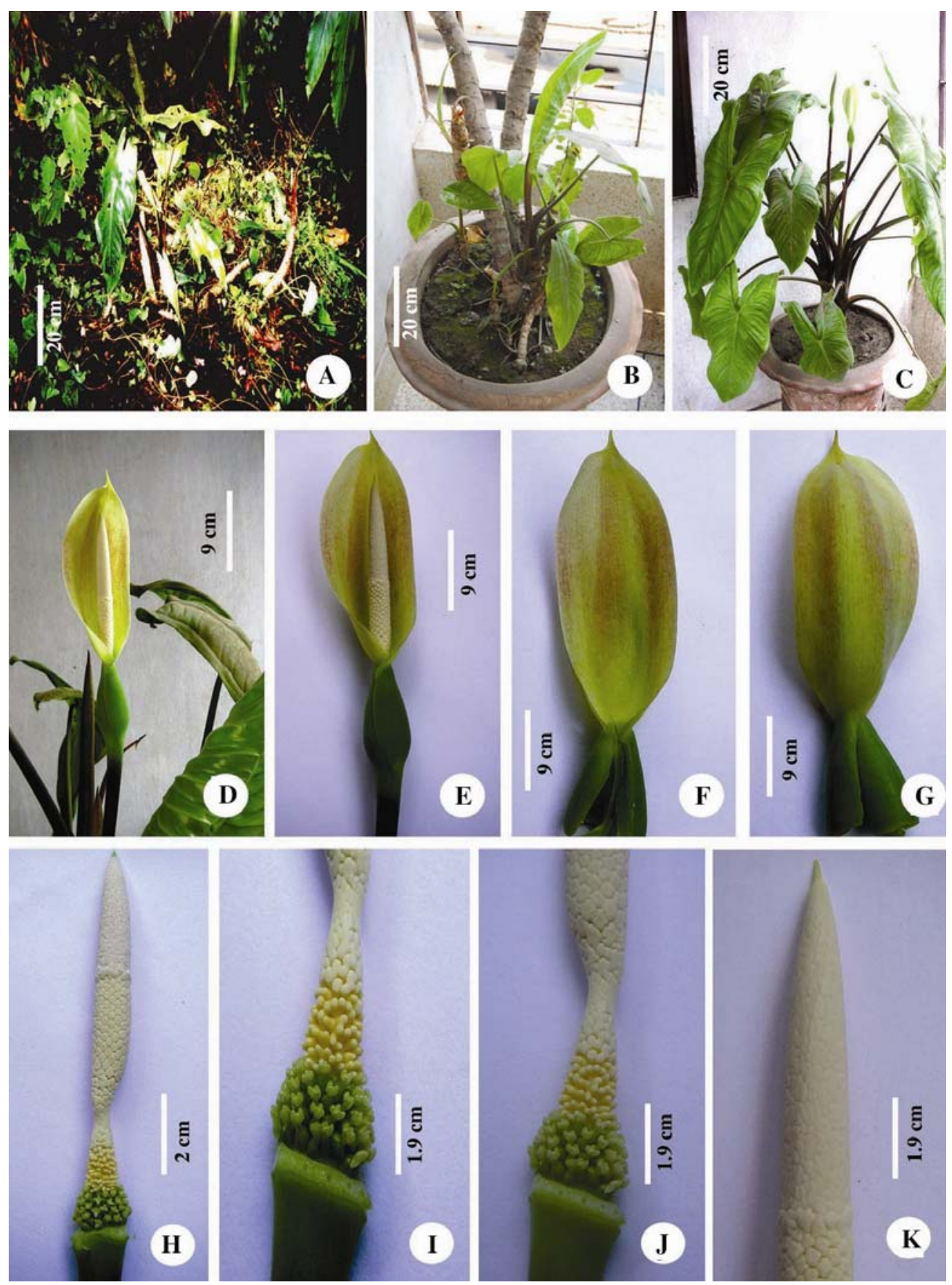

Fig. 4. Alocasia salarkhanii H. Ara \& M.A. Hassan, sp. nov.: A. Wild habitat; B,C. Habit-at home garden; D,E. Inflorescence; F. Inside of the spathe; G. Outside of the spathe; H. Spadix; I,J. Lower portion of the spadix; K. Appendix. 
corresponding with the spathe constriction; lower synandrodia often with incompletely connate staminodes, the rest elongate rhombo-hexagonal, flat-topped; male zone cyclindric, somewhat tapered at the base, c. $2.3 \mathrm{~cm}$ long, c. $0.8 \mathrm{~cm}$ thick, ivory in colour; synandria more or less hexagonal, c. $2 \mathrm{~mm}$ in diameter, androus; appendix c. $3.5 \mathrm{~cm}$ long, c. $0.8 \mathrm{~cm}$ thick at the middle, about the same thickness at the male zone, gradually tapering to a pointed tip, cream coloured. Fruit orange-red; fruiting peduncle $33-35 \mathrm{~cm}$ long, fruiting spathe ovoid, $4-6 \mathrm{~cm}$ long.

Flowering and fruiting period: May - August.

Chromosome number: $2 \mathrm{n}=28$ (Afroz et al., 2013).

Ecology: Grows on the hilly area as undergrowth.

Distribution: North-Eastern part of Bangladesh, Moulvibazar district.

Specimens examined: Moulvibazar: Lawachara reserve forest, 15.05.2005, Hosne Ara HA 1467 (DACB); 04.07.2005, Hosne Ara HA 1781 (DACB); Dhaka: Khilgaon, Tilpapara (Cultivated), 07.05.2006, Hosne Ara HA 2630 (DACB); Bangladesh National Herbarium garden (Cultivated), 30.05.2006, Hosne Ara HA 2651 (DACB) [Originally collected from Lawachara reserve forest under Moulvibazar districts].

Etymology: The species is named in honour of Dr. Md. Salar Khan, known as the father of plant taxonomy in Bangladesh.

The major morphological and cytological differences between the new species Alocasia salarkhanii H. Ara \& M.A. Hassan and its closely allied species Alocasia fornicata (Roxb.) Schott are outlined in Table 2 .

Table 2. Morphological and cytological comparison of Alocasia salarkhanii H. Ara \& M.A. Hassan, sp. nov. with its closely related Alocasia fornicata (Roxb.) Schott.

\begin{tabular}{lll}
\hline Characters & $\begin{array}{l}\text { Alocasia salarkhanii H. Ara \& } \\
\text { M.A. Hassan, sp. nov. }\end{array}$ & Alocasia fornicata (Roxb.) Schott \\
\hline Petiole and peduncle & Deep purple & Green \\
Leaf blade & Elliptic & Hastate \\
Inflorescence & In groups of up to 3 & In groups of 12, up to 25 \\
Style & c. $0.5 \mathrm{~mm}$ long & c. $1.0 \mathrm{~mm}$ long \\
Male zone & c. $2.3 \mathrm{~cm}$ long & c. $1.5 \mathrm{~cm}$ long \\
Appendix & Base of the appendix equal to the & Base of the appendix wider than the \\
& male zone & male zone \\
Chromosome number & 28 $(22 \mathrm{~m}+6 \mathrm{sm})$ & $28(18 \mathrm{~m}+10 \mathrm{sm})$ \\
CMA and DAPI & CMA-band and DAPI band absent & CMA-band and DAPI band present \\
\hline
\end{tabular}

$\mathrm{m}=$ metacentric chromosome, $\mathrm{sm}=$ submetacentric chromosome.

Conservation status: Critically Endangered (IUCN, 2017). Located in a very restricted area, should be conserved both by in situ and ex situ methods.

3. Typhonium elatum H. Ara \& M.A. Hassan, sp. nov.

(Figs 5 \& 6). Diagnosis: Typhonium elatum H. Ara \& M.A. Hassan differs from its closely related species $T$. trilobatum (L.) Schott by its green colour petiole which is more than $50 \mathrm{~cm}$ long; peduncle colour light green; length of the spathe c. $40 \mathrm{~cm}$ long and shape narrowly lanceolate; spadix length c. 29 $\mathrm{cm}$ long; base of the appendix multifurcate and colour of the staminode yellow. 


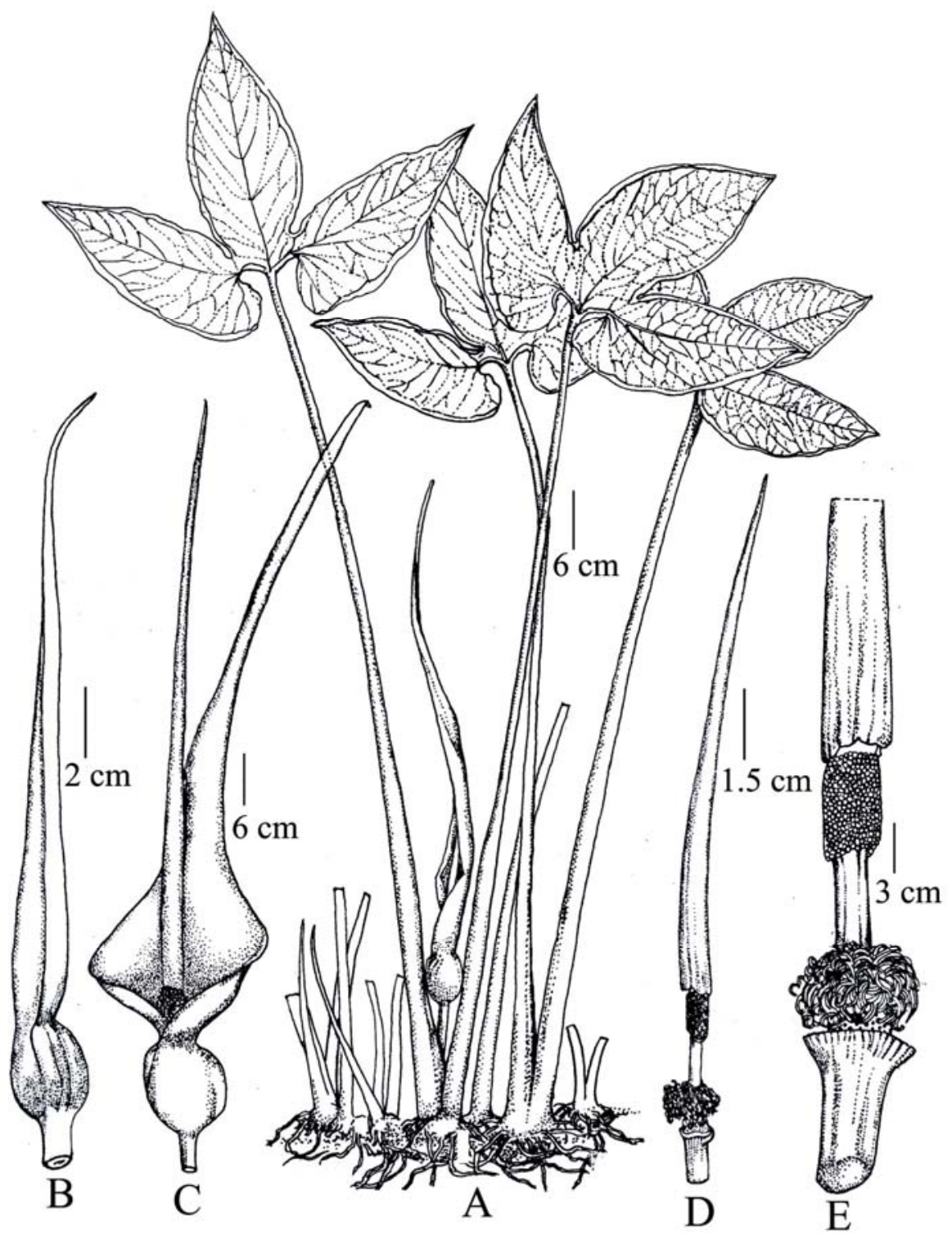

Fig. 5. Typhonium elatum H. Ara \& M.A. Hassan, sp. nov.: A. Habit; B. Spathe; C. Inflorescence; D. Spadix; E. Lower portion of the appendix, male zone and lower portion of the sapdix.

Holotype: Bangladesh, Sherpur district, Samaschura beat, 10.10.2003, Hosne Ara HA 701 (DACB).

Tuber c. $5 \mathrm{~cm}$ long, c. $4 \mathrm{~cm}$ in diameter, developing several offsets. Leaf paired; petioles up to $64 \mathrm{~cm}$ long, c. $1 \mathrm{~cm}$ in diameter, pale green. Leaf blade usually deeply trilobed, anterior lobe elliptic-lanceolate, up to c. $25 \mathrm{~cm}$ long, c. $13 \mathrm{~cm}$ in diameter, posterior lobe c. $19.5 \mathrm{~cm}$ long, c. 9 $\mathrm{cm}$ in diameter, bright pale green. Inflorescence paired. Peduncle c. $10 \mathrm{~cm}$ long, c. $0.8 \mathrm{~cm}$ in diameter, pale green. Spathe c. $40 \mathrm{~cm}$ long, tube and blade separated by a strong constriction; tube 

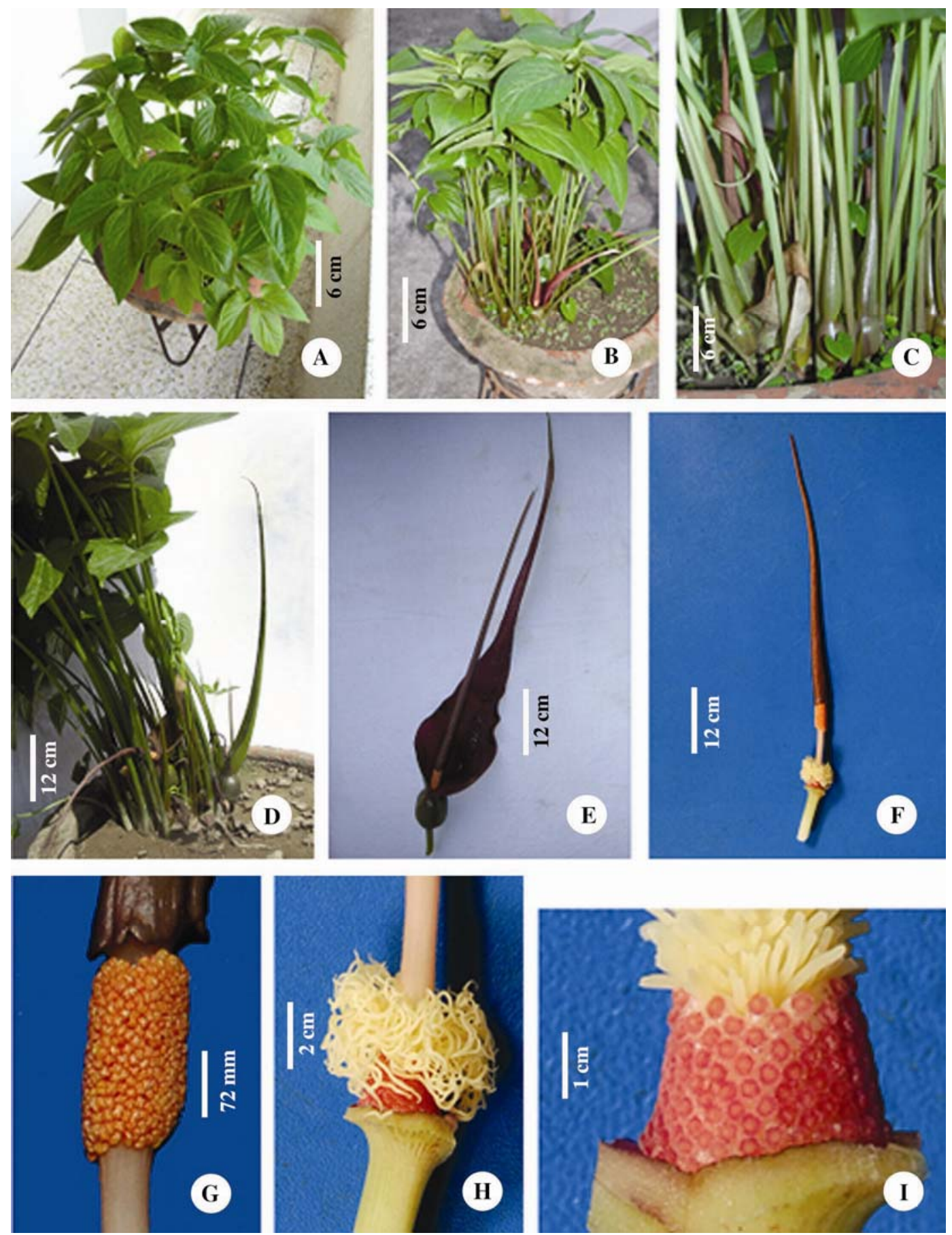

Fig. 6. Typhonium elatum H. Ara \& M.A. Hassan sp. nov.: A,B,C. Habit - at home garden; D,E. Inflorescence, F. Spadix; G. Male zone and lower portion of the appendix; H,I. Lower portion of the spadix. 
c. $3.5 \mathrm{~cm}$ long, outside pale green, inside glossy dark purple; blade c. $36.5 \mathrm{~cm}$ long, outside pale green, inside glossy dark purple. Spadix shorter than spathe, c. $29 \mathrm{~cm}$ long. Female zone c. $0.8 \mathrm{~cm}$ long, c. $0.8 \mathrm{~cm}$ in diameter, flowers congested; sterile zone between female and male zone, 2.7$4.0 \mathrm{~cm}$ long, the lower $0.5-2.2 \mathrm{~cm}$ with yellow staminodes, the remainder naked, light pink, longitudinally grooved; male zone cylindrical, c. $1.8 \mathrm{~cm} \mathrm{long,} \mathrm{c.} 1 \mathrm{~cm}$ in diameter, base and top oblique, flowers congested; appendix very shortly stipitate, narrowly lanceolate, $20-24 \mathrm{~cm} \mathrm{long,}$ c. $1 \mathrm{~cm}$ in diameter at the base, top acute, base multifurcate, with surface shallowly and irregularly furrowed, dark purple, producing a strong unpleasant smell at female anthesis. Stamens 0.6-0.9 $\mathrm{mm}$ long, light pinkish. Staminodes filiform, c. $1.6 \mathrm{~cm}$ long, c. $0.5 \mathrm{~mm}$ in diameter, dark yellowish, curled. Ovary elongate, cylindric, c. $1.5 \mathrm{~mm}$ long, 1.1-1.2 $\mathrm{mm}$ in diameter, white with a faint pinkish flush near the top, unilocular, with one basal ovule; stigma sessile, depressed, hemispheric, c. $0.8 \mathrm{~mm}$ in diameter, c. $0.2 \mathrm{~mm}$ high, papillose, pink. Fruit not observed, usually die before fruit formation.

Flowering period: March - October.

Chromosome number: $2 \mathrm{n}=18$ (Huq et al., 2007).

Ecology: Grows on the hilly area as undergrowth.

Distribution: Central parts of Bangladesh (Sherpur district).

Specimen examined: Sherpur: Samaschura beat, 10.10.2003, Hosne Ara. HA 701 (DACB); ibid, 23.06.2004, Hosne Ara HA 1060 (DACB); Dhaka: Khilgaon, Tilpapara (Cultivated), 02.07.2015, Hosne Ara HA 2889 (DACB) [Originally collected from Samaschura beat under Sherpur district].

Etymology: The species is named after tallness of its habit.

The major morphological and cytological differences between the new species Typhonium elatum H. Ara \& M.A. Hassan and its closely allied species Typhonium trilobatum (L.) Schott are presented in Table 3.

Table 3. Morphological and cytological comparison of Typhonium elatum H. Ara \& M.A. Hassan, sp. nov. with Typhonium trilobatum (L.) Schott.

\begin{tabular}{lll}
\hline Characters & $\begin{array}{l}\text { Typhonium elatum H. Ara \& M.A. } \\
\text { Hassan, sp. nov. }\end{array}$ & Typhonium trilobatum (L.) Schott \\
\hline Petiole & Green, $\geq 50 \mathrm{~cm}$ long & Purple, $\leq 45 \mathrm{~cm}$ long \\
Leaf shape & Elliptic lanceolate & Ovate, ovate-lanceolate \\
Peduncle & Light green & Purple \\
Spathe & c. $40 \mathrm{~cm}$ long, narrow lanceolate & $15-18 \mathrm{~cm}$ long, ovate to broadly ovate \\
Spadix length & c. $29 \mathrm{~cm}$ long & c. $13.5 \mathrm{~cm}$ long \\
Appendix & Base of the appendix multifurcate & Base of the appendix truncate \\
Staminodes & Yellow & White \\
Ovary & c. $1.5 \mathrm{~mm}$ long, c. 1.2 mm in & c. $1.0 \mathrm{~mm}$ long, c. 0.7 mm in diameter, \\
& diameter, white with a faint & cream colour \\
pinkish flush near the top & \\
Chromosome number & $18(12 \mathrm{~m}+6 \mathrm{sm})$ & DAPI band 3 \\
DAPI band & DAPI band 5 &
\end{tabular}

$\mathrm{m}=$ metacentric chromosome, $\mathrm{sm}=$ submetacentric chromosome.

Note : Although the two species bear same chromosome number, they differ by the karyotype formulae and DAPI characters. 
Conservation status: Endangered (IUCN, 2017). Collected from a single locality, now conserved through ex situ in a home garden.

\section{Acknowledgements}

The authors are grateful to the authorities of the BK, BKF, BM, CAL, DACB, K, DUSH, HCU, BCSIRH and BFRIH for providing facilities to consult aroid materials and their libraries. The authors express their gratitude to Professor Dr. M. Oliur Rahman, Department of Botany, University of Dhaka for his encouragement and enormous help during preparation of the manuscript. Thanks are also due to Ms. Mahmuda Akter, Senior Artist-cum-illustrator, Bangladesh National Herbarium for drawing the illustrations, and the researchers at Cytogenetics Laboratory of the Department of Botany, University of Dhaka for their cooperation in chromosomal investigation of the new species.

\section{References}

Afroz, M., Sultana, S.S. and Alam, S.S. 2013. Karyotype and RAPD analysis of three morphological forms of Alocasia fornicata (Roxb.) Schott. Cytologia 78(3): 269-275.

Ara, H. 2016. Taxonomic studies in the family Araceae from Bangladesh. Ph.D. Thesis (unpublished), Department of Botany, University of Dhaka, Bangladesh, pp. 1-524.

Boyce, P.C. 2007. Studies on the Alocasia Schott (Araceae-Colocasieae) of Borneo: I. Two new species from Sarawak, Malaysian Borneo. Gard. Bull. Singapore 58(2): 141-154.

Boyce, P.C. and Croat, T.B. 2011 (onwards). The Überlist of Araceae, Totals for Published and estimated number of species in Aroid Genera. http://www.aroid.org/genera/180211 uberlist.pdf. (Accessed 05 November 2018).

Engler, A 1920. Araceae-Aroideae, Araceae-Pistiodeae. In: Engler, A. (Ed.), Das Pflanzenreich 73 (IV. 23F): $1-274$.

Engler, A. and Krause, K. 1920. Additamentum ad Araceas-Philodendroideas, Araceae-Colocasioideae. In: Engler, A. (Ed.), Das Pflanzenreich 71 (IV.23E): 3-132.

Hay, A. 1991. The Genus Alocasia (Araceae) in Australasia. Blumea 35: 499-545.

Hay, A. 1993. The genus Typhonium (Araceae-Areae) in Australasia. Blumea 37(2): 345-376.

Hay, A. 1998. Alocasia in West Malesia and Sulawesi. Gard. Bull. Singapore 50(2): 325-327.

Hay, A. 1999. Alocasia in the Philippines. Gard. Bull. Singapore 51: 29-30.

Hetterscheid, W.L.A. and Boyce, P.C. 2000. A reclassification of Sauromatum Schott and new species of Typhonium Schott (Araceae). Aroideana 23: 48-55.

Hooker, J.D. 1893 (Reprint 1954). The Flora of British India, Vol. 6. L. Reeve \& Co. Ltd., Kent, England, pp. $490-555$.

Hu, S.Y. 1968. Araceae. Studies in the Flora of Thailand, no. 41. Dansk Bot. Arkiv 23(4): 409-457.

Huq, S., Ara, H., Hassan, M.A. and Alam, S.S. 2007. Comparative karyotype analysis of Typhonium trilobatum L. and its two morphological forms. Cytologia 72(2): 233-238.

IUCN 2017. Studies and Petitions Subcommittee Guidelines for Using the IUCN Red List http://www.incnredlist.org/documents/RedListGudelines.pdf. pp. 1-108.

Jackson, B.D. 1893-1955. Index Kewensis (An Eumeration of the Genera and Species of Flowering Plants). Vols. 1 \& 2. Oxford at the Clardon press.

Karthikeyan, S., Jain, S.K., Nayar, M.P. and Sanjappa, M. 1989. Florae Indicae Enumeratio: Monocotyledonae. Flora of India Series 4. Araceae. Botanical Survey of India, Calcutta, pp. 5-15.

Li, H., Zhu, G., Boyce, P.C., Murata, J., Hetterscheid, W.L.A., Bogner, J. and Jacobsen, N. 2010. Araceae. In: Wu, Z.Y., Raven, P.H. and Hong, D.Y. (Eds). Flora of China, Vol. 23 (Acoraceae through Cyperaceae). Science Press, Beijing, and Missouri Botanical Garden Press, St. Louis. pp. 3-79. 
Mayo, S.J. 1985. Araceae. In: Polhill, R.M. (Ed.), Flora of Tropical East Africa. Balkema, Rotterdam, the Netherlands, pp.1-71.

Mayo, S.J., Bogner, J. and Boyce, P.C. 1997. The Genera of Araceae. Royal Botanic Gardens, Kew, UK, pp. $1-370$.

Nasir, Y.J. 1978. Araceae. In: Nasir, E. and Ali, S.I. (Eds), Flora of West Pakistan, No. 120. Agricultural Research Council, Islamabad, Pakistan, pp.1-17.

Nicolson, D.H. 1976 (Reprint 1978). Araceae. In: Saldanha, C.J. and Nicolson, D.H. (Eds), Flora of Hassan District, Karnataka, India. Amerind Publishing Co. Pvt. Ltd., New Delhi, Bombay, Calcutta and New York, pp. 781-790.

Nicolson, D.H. 1979. Araceae. In: Smith, A.C. (Ed.), Flora Vitiensis Nova, Vol. 1. Pacific Tropical Botanical Garden, Hawaii, pp. 438-460.

Nicolson, D.H. 1987. Araceae. In: Dassanayake, M.D. (Ed.), A Revised Handbook to the Flora of Ceylon, Vol. 6. Balkema, Rotterdam, the Netherlands, pp. 17-101.

Nicolson, D.H. and Sivadasan, M. 1981. Four frequently confused species of Typhonium Schott (Araceae). Blumea 27(2): 483-497.

Noltie, H.J. 1994. Araceae. In: Grierson, J.D. and Long, D.G. (Eds), Flora of Bhutan, Vol. 3(1). Royal Botanic Garden, Inverleith Row, Edinburgh, UK, pp. 121-158.

Prain, D. 1903. Bengal Plants, Vol. 2. Indian reprint (1963), Botanical survey of India, Calcutta, pp. 830-840.

Roxburgh, W. 1832. Tetrandia Monogynia in Willium Carey's Flora Indica; or Descriptions of Indian Plants. Mission Press, Serampore, India, pp. 620-635.

Sookchaloem, D. 1995. Typhonium (Araceae) in Thailand. Thai For. Bull. (Bot.) 23: 18-39.

Sriboonma, D., Murata, J. and Iwatsuki, K. 1994. A revision of Typhonium (Araceae). J. Fac. Sci. Univ. Tokyo, Sect. III. 15: 255-313.

Sultana, S.S., Ara, H. and Alam, S.S. 2011. Karyotype analysis with Orcein and CMA in two species of Alocasia (Schott) G. Don (Araceae). Bangladesh J. Bot. 40(1): 53-56.

Toha, A.M.M. 2000. Biodiversity of aroids in southeast Bangladesh. M. Phil Thesis (unpublished). Aberdeen University, Scotland, U.K.

Wallich, N. 1829-1849. A numerical list of dried specimens of plants in the East Indian Company's Museum. Generally cited Wall. Cat., ined.

Wight, R. 1843-1845. Icones Plantarum Indiae Orientalis or Figures of Indian Plants, Vol. 3 (Part 1). Messrs, Ostell, Lepage and Co., Calcutta, pp. 772-808. 